\title{
Mobile Phone Interventions for Adolescent Sexual and Reproductive Health: A Systematic Review
}

Kelly L. L'Engle, PhD, MPH, a Emily R. Mangone, MSc, ${ }^{\text {b }}$ Angela M. Parcesepe, PhD, MPH, MSW, S Smisha Agarwal, MPH, MBA, BDS, b,d Nicole B. Ippoliti, MPHe

CONTEXT: Interventions for adolescent sexual and reproductive health (ASRH) are increasingly using mobile phones but may not effectively report evidence.

OBJECtive: To assess strategies, findings, and quality of evidence on using mobile phones to improve ASRH by using the mHealth Evidence Reporting and Assessment (mERA) checklist recently published by the World Health Organization mHealth Technical Evidence Review Group.

DATA SOURCES: Systematic searches of 8 databases for peer-reviewed studies published January 2000 through August 2014.

StUdy SELECtION: Eligible studies targeted adolescents ages 10 to 24 and provided results from mobile phone interventions designed to improve ASRH.

DATA EXTRACTION: Studies were evaluated according to the mERA checklist, covering essential mHealth criteria and methodological reporting criteria.

RESULTS: Thirty-five articles met inclusion criteria. Studies reported on 28 programs operating at multiple levels of the health care system in 7 countries. Most programs (82\%) used text messages. An average of $41 \%$ of essential mHealth criteria were met (range $14 \%$ $79 \%$ ). An average of $82 \%$ of methodological reporting criteria were met (range $52 \%-100 \%$ ). Evidence suggests that inclusion of text messaging in health promotion campaigns, sexually transmitted infection screening and follow-up, and medication adherence may lead to improved ASRH.

LIMIтATIONS: Only 3 articles reported evidence from lower- or middle-income countries, so it is difficult to draw conclusions for these settings.

concLusions: Evidence on mobile phone interventions for ASRH published in peer-reviewed journals reflects a high degree of quality in methods and reporting. In contrast, current reporting on essential mHealth criteria is insufficient for understanding, replicating, and scaling up mHealth interventions.

\footnotetext{
${ }^{a}$ School of Nursing and Health Professions, University of San Francisco, California; ${ }^{b}$ Gillings School of Global Public Health, University of North Carolina Chapel Hill, Chapel Hill, North Carolina; ${ }^{c}$ HIV Center for Clinical and Behavioral Studies, Columbia University and New York State Psychiatric Institute, New York, New York; ${ }^{d}$ Department of International Health Johns Hopkins Bloomberg School of Public Health, Baltimore, Maryland; and ${ }^{\mathrm{F} H \mathrm{FI}} 360$, Durham, North Carolina

Dr L'Engle conceptualized and designed the study, analyzed and interpreted the data, and drafted the initial manuscript; Ms Mangone performed the literature search, data coding, and extraction, contributed to the interpretation of data, and drafted portions of the initial manuscript; Dr Parcesepe participated in the literature review, performed data coding and analysis, and critically reviewed the manuscript; Dr Agarwal performed data coding and analysis and critically
}

To cite: L'Engle KL, Mangone ER, Parcesepe AM, et al. Mobile Phone Interventions for Adolescent Sexual and Reproductive Health: A Systematic Review. Pediatrics. 2016;138(3):e20160884 
Globally, mobile phone use is increasingly rapidly, and a large proportion of mobile phone subscribers are young people. ${ }^{1,2}$ Four of every 5 citizens in developed countries and 1 of every 2 citizens in developing countries have a mobile phone subscription. ${ }^{3}$ Young people $\leq 29$ years of age are the most likely to own a mobile phone, ${ }^{2,4}$ and 15- to 24-year-olds are more likely than older age groups to own a smartphone, indicating this group's eagerness to use new mobile technologies. ${ }^{2,5,6}$ Given their popularity among youth, adolescent health professionals are increasingly using mobile phones to link young people to health information and services across global settings. ${ }^{7-10}$

This promising approach is called mHealth, the use of mobile phones to improve health knowledge, behaviors and outcomes, and it has advantages when used in health programming for young people. Adolescents commonly report low sexual and reproductive health (SRH) knowledge and risky sexual behaviors, ${ }^{11,12}$ but they also face barriers to care such as provider bias and fear of stigma, refusal, and embarrassment in seeking information and services. ${ }^{13-17}$ Mobile phone solutions may help overcome many of these barriers by providing accurate, timely, and engaging information and appropriate care for highly sensitive adolescent sexual and reproductive health (ASRH) topics. Mobile phones are inexpensive, portable, and accessible. They offer privacy in comparison with face-to-face meetings with health care providers, and they can provide young people with tailored and anonymous health information without stigma or judgment.

Furthermore, young people are responsive to and excited about using new technologies for SRH promotion. ${ }^{18-21}$

Better assessments of mHealth solutions for young people are needed to rigorously evaluate whether they are a viable and effective strategy for reaching adolescents and improving ASRH behaviors in particular. Although a few published reviews have examined digital health solutions to ASRH, none have focused exclusively on mobile phone interventions and used a comprehensive definition of ASRH. ${ }^{8-10}$ The goals of this research are to assess the strategies, findings, and reporting quality from evidence on mobile phone interventions for ASRH.

We conducted a systematic review of research from peer-reviewed journal articles by using the new mHealth Evidence and Reporting Assessment (mERA) checklist. ${ }^{22}$ The checklist was developed by the World Health Organization mHealth Technical Evidence Review Group specifically to assess evidence from mobile phone intervention research for health improvement. The recently published mERA checklist is a valuable tool to assess the quality and completeness of intervention reporting for the many mHealth interventions for ASRH. Effective and comprehensive reporting may help improve program design, foster collaboration between service providers, reduce duplication of efforts, and ultimately increase the impact and ability to scale effective mHealth interventions for ASRH.

\section{METHODS}

\section{Search Strategy}

In August 2014 we searched 8 databases in the fields of medicine and social science: PubMed, Embase, Global Health, PsycINFO, Popline, Cochrane Library, Web of Science, and mHealthevidence.org. Search terms were grouped under 3 domains: adolescence, SRH, and mobile technology (Supplemental Table 6). Because our interest was in the intersection of these domains, the presence of $\geq 1$ search term from each domain was required for inclusion. We also hand-searched the references of 21 relevant systematic reviews. Finally, we issued a global call for resources on mHealth interventions for ASRH, which was widely promoted via social media, relevant electronic mailing lists, and partner Web sites.

\section{Eligibility}

We took an inclusive approach and used the World Health Organization definition of young people ages 10 to $24^{23}$ and included peer-reviewed articles that either presented disaggregated data for young people 10 to 24 or did not disaggregate results but described the sample as having $\geq 70 \%$ of respondents between 10 and 24 years of age. We used the United Nations Family Planning Association definition of sexual and reproductive health, ${ }^{24}$ which includes contraception, antenatal care, delivery, postnatal care, infertility, abortion, reproductive tract infections, HIV/AIDS, sexually transmitted infections (STIs), sexuality, and violence against women and related practices (eg, female genital mutilation). Included articles also had to describe the use of a mobile device, such as a mobile phone or tablet, to provide SRH information and support, and describe results or feedback from the mobile technology intervention. Systematic reviews, gray literature, documents that were not in English, and documents published before January 1, 2000 were excluded.

\section{Literature Search Results}

The Preferred Reporting Items for Systematic Review and MetaAnalyses (PRISMA) flow diagram was used to document the search strategy and article selection process (Fig 1). ${ }^{25} \mathrm{~A}$ total of 5040 articles were retrieved from the 8 databases described above. After we removed duplicate articles and articles published before January 1, 2000, 2806 records remained. 


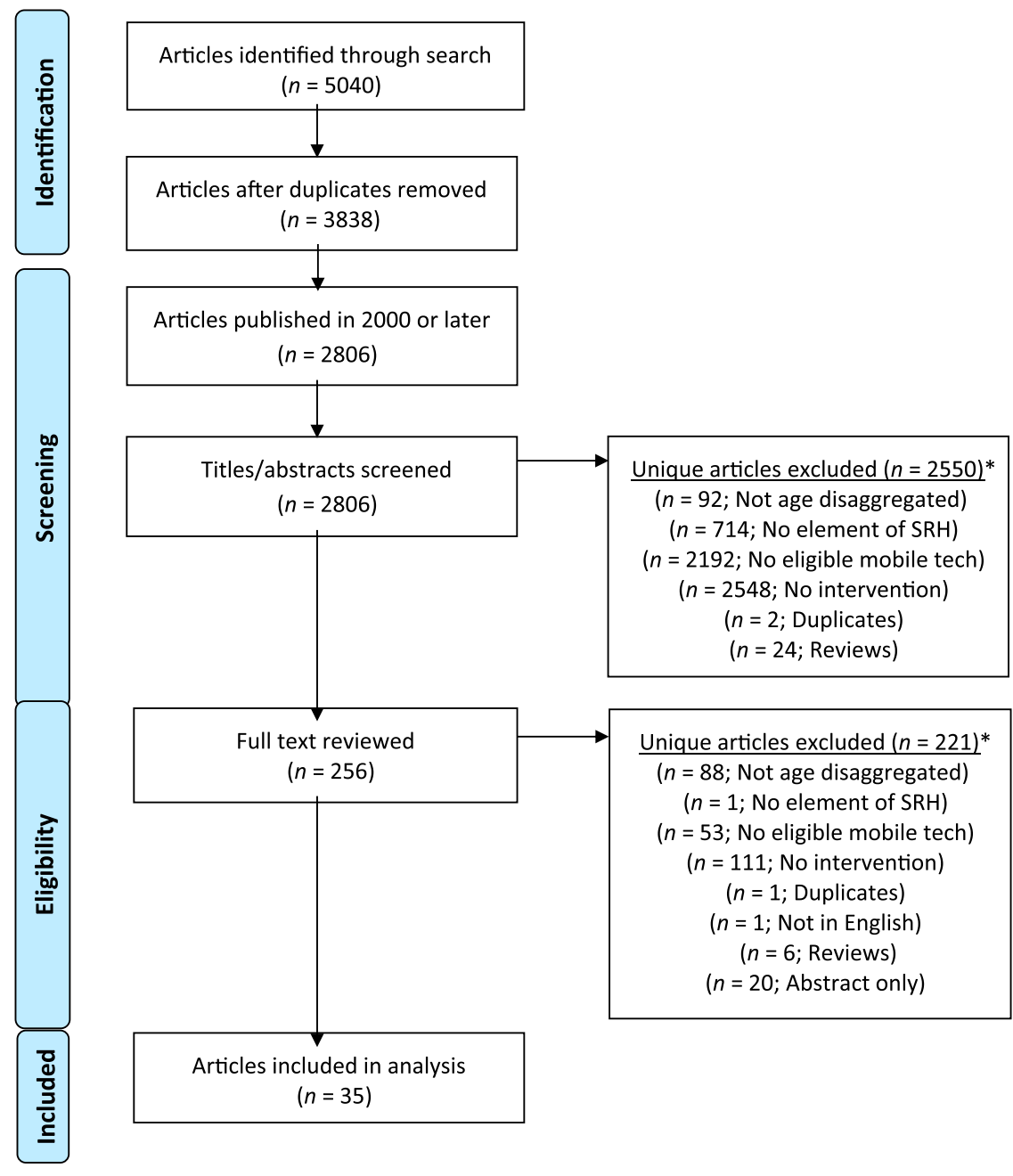

FIGURE 1

PRISMA flow diagram of article inclusion.

All 2806 titles and abstracts were screened and resulted in the exclusion of 2550 unique records; records could be excluded for multiple reasons. The full texts of the 256 remaining records were screened and resulted in the final inclusion of 35 articles. No additional articles meeting inclusion criteria were identified through the search of systematic reviews or through the global call for evidence.

Two reviewers screened a random selection of $11 \%$ of all abstracts ( $n=300$ out of 2806) for inclusion in the study. There was $94 \%$ agreement on article inclusion between the reviewers. Another check was conducted for $20 \%$ of documents ( $n=50$ out of 256) at the full text level. Again, this resulted in a high interrater reliability agreement of $92 \%$. When reviewers did not agree, a third reviewer was consulted to make the final determination about whether the article met eligibility criteria for inclusion.

\section{Data Extraction and Synthesis}

One reviewer extracted data from included studies and a second reviewer independently confirmed accuracy. Data extraction for each article included name of the mHealth intervention program, study design, population, and aim, and key results. Study design (for each individual article) and program purpose (for each unique mHealth program) were used as classification schemes for synthesizing data. Study designs were cataloged as randomized controlled trials (RCTs), quasiexperimental, observational, or descriptive research. Program purpose included health promotion campaign, curriculum addition, screening and follow-up service utilization, provider counseling, and patient adherence.

\section{Grading}

Evidence was graded according to the mERA checklist. ${ }^{22}$ The core checklist defines 14 essential mHealth criteria to support completeness of reporting and replication of the mHealth intervention by addressing its content, context, and implementation features (Supplemental Table 7). In addition, mERA also provides a checklist for reporting on study methods, because the field of mHealth includes a range of research designs and methods. This second checklist defines 30 core elements of research reporting required to facilitate the synthesis of mHealth research findings, regardless of study design (Supplemental Table 8).

This manuscript is the first review of published literature to use the mERA checklist. Three reviewers were trained on the mERA checklist, and they graded 4 randomly selected articles to yield interrater reliability scores of $82 \%, 84 \%, 93 \%$, and $95 \%$, sequentially.

\section{RESULTS}

\section{Program Strategies}

The 35 articles reported on 28 different mHealth intervention programs where mobile phones were used to address ASRH. Threequarters of all programs $(n=21)$ were implemented in the United States. Four were conducted in Australia or New Zealand, and 1 was conducted in the Netherlands. One program was implemented in Tanzania and 1 in the Democratic Republic of the Congo. 


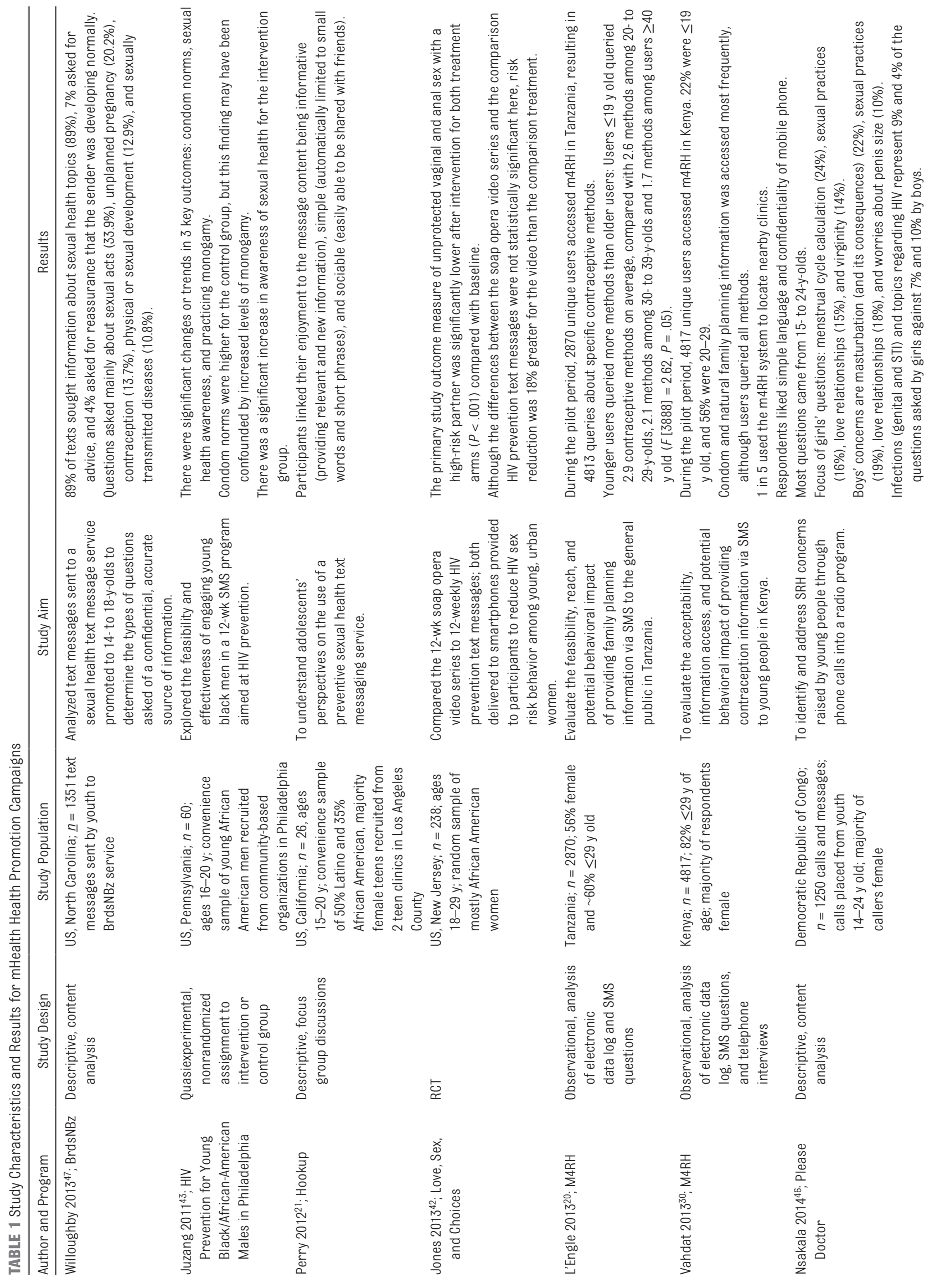




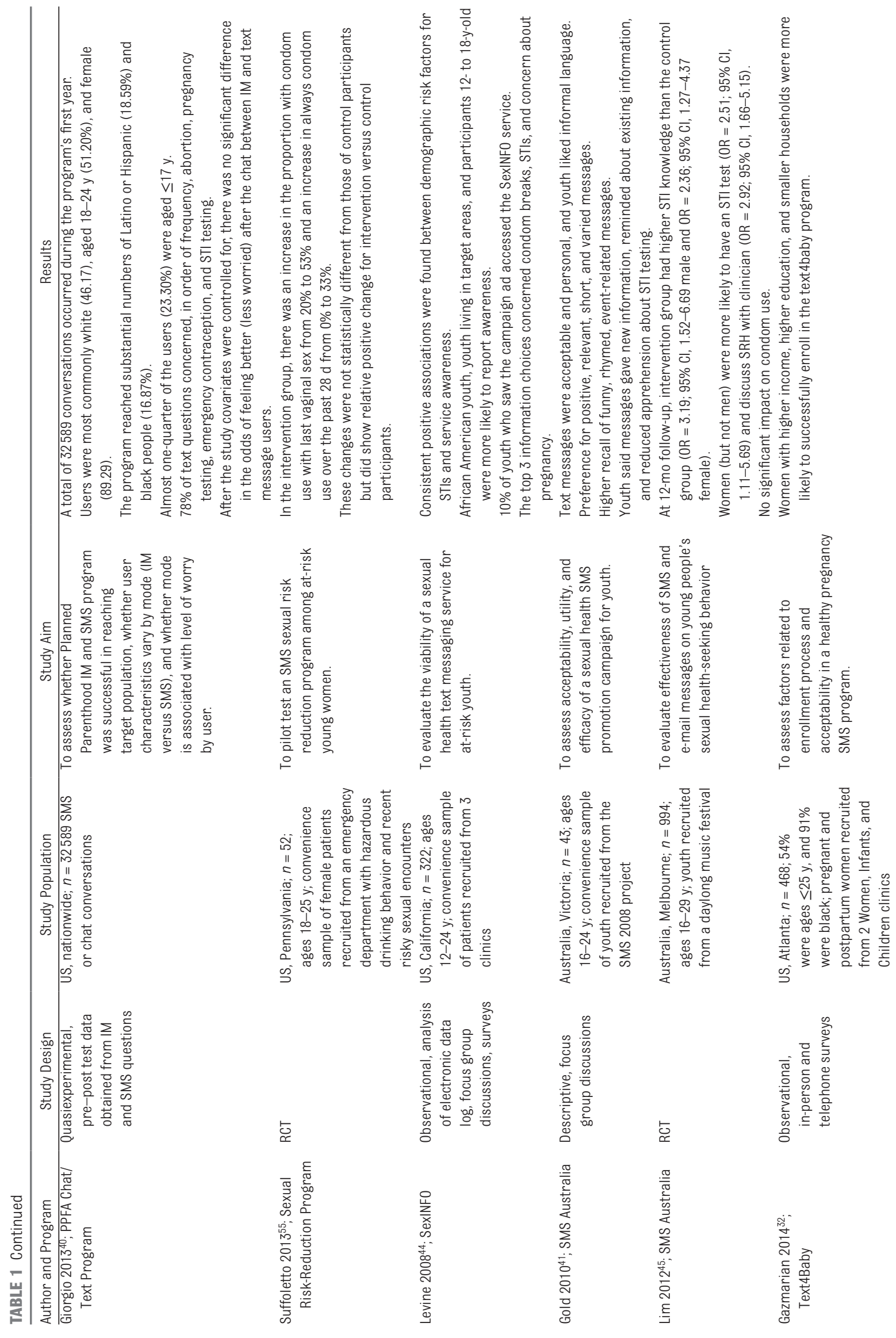


Eight programs focused on pregnancy; 4 of these aimed to increase adoption and correct use of contraceptive methods, ${ }^{20,26-30} 2$ focused on youth assets and broader pregnancy prevention messaging, 19,31 and 2 provided information to pregnant or parenting adolescents. ${ }^{32,33}$ STIs were the focus of 8 programs, with most of them targeting links to services for STI vaccination, ${ }^{34,35}$ screening, ${ }^{36,37}$ or treatment. ${ }^{10,34,38,39}$ Seven programs targeted general ASRH issues. ${ }^{40-47}$ Five mHealth programs specifically focused on HIV/AIDS; 3 of them provided adherence support for HIV-positive youth, ${ }^{48-51}$ and 2 focused on HIV prevention. ${ }^{18,43,52,53}$

Health promotion campaigns were the most common purpose of mHealth programs for ASRH included in the review $(43 \% ; n=12)$. These programs provided a mobile phone platform for youth to text SRH questions to health professionals, ${ }^{33,40,46,47}$ allowed adolescents to retrieve on-demand SRH content, ${ }^{20,30,44}$ and offered "push" messaging where SRH content was texted to adolescents on a regular schedule. 21,32,41,43,45,51 Two programs complemented delivery of an in-person, evidence-based ASRH curriculum with a mobile phone component to extend program reach particularly to ethnic and minority youth and to stay current on the communication channels frequently used by young people. ${ }^{18,19,52,53}$

The 7 mHealth programs for screening and follow-up service utilization included human papillomavirus (HPV) vaccination text message reminders for follow-up, ${ }^{34,35}$ notification for positive chlamydia and other STI results, ${ }^{10,38,53,54}$ and chlamydia screening promotion. ${ }^{36,37}$ Patient adherence to medications or health recommendations was addressed in 7 additional programs that provided text message reminders for taking daily oral contraceptive pills ${ }^{27,28}$ or antiretroviral therapy (ART) for HIV-positive young people ${ }^{49,50}$ and in programs that provided regular counseling over the mobile phone to improve adherence to contraception use and continuation ${ }^{26,29}$ or adherence to ART for HIV-positive youth ${ }^{48,51}$ or to delay subsequent pregnancy among adolescent mothers. ${ }^{31}$

Short message service (SMS) or text messaging was used by the majority of programs $(82 \%, n=23)$. Three programs added mobile phone voice calls, ${ }^{39,46,54}$ and 4 programs used mobile phone voice calls exclusively. ${ }^{26,29,31,48,51}$ Only a few programs used other communication formats, such as providing mobile phone videos, ${ }^{42}$ e-mail, ${ }^{37}$ instant messaging, ${ }^{40}$ or sparse use of other multimedia applications. ${ }^{18,52,53}$

\section{Study Findings}

Research on health promotion interventions (Table 1) that provided a forum for asking SRH questions confidentially via mobile phone ${ }^{33,40,46,47}$ found that adolescents texted about a wide range of highly sensitive SRH topics, suggesting robust acceptability and relevance of this strategy. Content analyses of text questions found that adolescents commonly asked about sexual acts and practices ${ }^{46,47}$ physical and sexual development, ${ }^{47}$ abortion, ${ }^{40}$ and contraception and unplanned pregnancy. ${ }^{40,47}$ However, a comprehensive array of SRH topics was mentioned in adolescents' texts.

Health promotion campaigns that provided on-demand or pushed out mobile phone messages were found to be highly acceptable to young people $20,21,29,32,41,43-45,55$ because they liked the confidentiality of mobile phone communication ${ }^{30}$ and found the SRH content simple to understand, ${ }^{21,30}$ informative, ${ }^{21,41,55}$ and easily shared. ${ }^{21,30}$ Furthermore, research on these campaigns along with a study on a mobile phone curriculum addition ${ }^{53}$ (Table 2) demonstrated that mHealth 
TABLE 2 Study Characteristics and Results for mHealth Curriculum Additions

\begin{tabular}{|c|c|c|c|c|}
\hline $\begin{array}{l}\text { Author and } \\
\text { Program }\end{array}$ & Study Design & Study Population & Study Aim & Results \\
\hline $\begin{array}{c}\text { Cornelius 201152; } \\
\text { BART Booster }\end{array}$ & $\begin{array}{l}\text { Observational, } \\
\text { analysis of } \\
\text { electronic data log, } \\
\text { group discussions }\end{array}$ & $\begin{array}{l}\text { US, Southeast; } n= \\
\text { 12; ages } 13-18 \mathrm{y} ; \\
\text { convenience sample } \\
\text { of African American } \\
\text { teens, majority female }\end{array}$ & $\begin{array}{l}\text { To develop and pretest } \\
\text { multimedia and SMS } \\
\text { messaging as boosters } \\
\text { for evidence-based HIV } \\
\text { prevention curriculum } \\
\text { (BART), in a 3-wk theater } \\
\text { test of platform. }\end{array}$ & $\begin{array}{l}\text { Teens indicated interest in receiving safer sex } \\
\text { information in natural setting, via mobile, and in } \\
\text { familiar language. } \\
\text { Technical challenges in message delivery were identified } \\
\text { and corrected. } \\
\text { Over } 3 \text {-wk testing period, observed average of } 80 \% \\
\text { response to text messages. }\end{array}$ \\
\hline $\begin{array}{c}\text { Cornelius } 2012^{18} \text {; } \\
\text { BART Booster }\end{array}$ & $\begin{array}{l}\text { Descriptive, focus } \\
\text { group discussion }\end{array}$ & $\begin{array}{l}\text { US, Southeast; } n= \\
\text { 11; age } 13-18 \mathrm{y} ; \\
\text { convenience sample } \\
\text { of African American } \\
\text { teens, equal numbers } \\
\text { male and female }\end{array}$ & $\begin{array}{l}\text { Examine African American } \\
\text { adolescents' perceptions } \\
\text { of a mobile phone- } \\
\text { enhanced BART booster } \\
\text { intervention. }\end{array}$ & $\begin{array}{l}\text { Adolescents liked the approach of using mobile phones to } \\
\text { provide HIV messages. } \\
\text { Preferred message delivery } 1 \text { per } d \text {. } \\
\text { Perceived benefits were ease of use, anonymity, } \\
\quad \text { confidentiality, and support on demand. }\end{array}$ \\
\hline $\begin{array}{c}\text { Cornelius 201353; } \\
\text { BART Booster }\end{array}$ & $\begin{array}{l}\text { Quasiexperimental, } \\
\text { longitudinal } \\
\text { 1-group } \\
\text { comparison with } \\
\text { baseline and } 2 \\
\text { follow-ups }\end{array}$ & $\begin{array}{l}\text { US, Southeast; } n= \\
\text { 40; ages 13-18 y; } \\
\text { convenience sample } \\
\text { of African American } \\
\text { teens recruited } \\
\text { from community } \\
\text { organizations and } \\
\text { schools, equal } \\
\text { numbers male and } \\
\text { female }\end{array}$ & $\begin{array}{l}\text { Whether change in beliefs } \\
\text { and sexual behavior } \\
\text { among African Americans } \\
\text { could be achieved } \\
\text { through a mobile } \\
\text { phone HIV prevention } \\
\text { intervention. }\end{array}$ & $\begin{array}{l}\text { Greater HIV knowledge, improved attitudes toward } \\
\text { condoms, and increased perceived HIV risk scores } \\
\text { were observed with older adolescents ( } 16-18 \text { y old). } \\
\text { Reported decrease in engaging in unprotected sexual } \\
\text { intercourse from } 31 \text { times at baseline to } 19 \text { times } \\
\text { after intervention and then only } 9 \text { times at the } 3 \text {-mo } \\
\text { follow-up. }\end{array}$ \\
\hline $\begin{array}{l}\text { Devine } 2014^{19} ; \\
\text { Teen Outreach } \\
\text { Program }\end{array}$ & $\begin{array}{l}\text { Observational, } \\
\text { analysis of } \\
\text { electronic data } \\
\text { log, focus group } \\
\text { discussions }\end{array}$ & $\begin{array}{l}\text { US, Colorado; } n= \\
\text { 96; ages } 14-18 \mathrm{y} ; \\
\text { convenience sample } \\
\text { of } 70 \% \text { Latino and } \\
24 \% \text { African American } \\
\text { teens, majority male, } \\
\text { recruited from Boys } \\
\text { and Girls Clubs of } \\
\text { Colorado }\end{array}$ & $\begin{array}{l}\text { To develop and pilot a } \\
\text { theory-based mobile } \\
\text { phone texting component } \\
\text { attractive to minority } \\
\text { youth as a supplement } \\
\text { to the evidence-based } \\
\text { Teen Outreach Program, } \\
\text { a youth development } \\
\text { program for reducing } \\
\text { teen pregnancy and } \\
\text { school dropout. }\end{array}$ & $\begin{array}{l}\text { Teens were enthusiastic about text messages } \\
\text { complementing Teen Outreach Program. } \\
\text { Results also revealed barriers: access to mobile phones, } \\
\text { retention as measured by completion of the postpilot } \\
\text { survey, and a need to be attentive to teen literacy. } \\
\text { Observed a } 49 \% \text { response to text messages and a } \\
\text { decrease in response rates over time. } \\
\text { Messages were viewed as too frequent and revised to } \\
\text { send 3-7 per week. }\end{array}$ \\
\hline
\end{tabular}

BART, becoming a responsible teen.

intervention exposure was associated with increased sexual health knowledge and awareness, $33,43,45,53$ lower rates of unprotected sex and higher rates of condom use, ${ }^{42,53,55}$ and greater STI testing. ${ }^{45}$

Several studies of health promotion campaigns investigated levels of mHealth program access among adolescents and lower-income and minority subgroups. Results pointed to a few programs that have successfully reached the general youth population in Africa ${ }^{20,30,46}$ and specific youth subgroups at higher risk of negative SRH outcomes in the United States. ${ }^{40,44}$ For example, more than half of the Planned Parenthood Federation of America (PPFA) Chat/Text program users in year 1 were African American,
Latino, or from other ethnic or racial minority groups, ${ }^{40}$ and the Mobile for Reproductive Health (m4RH) program in Kenya found that 22\% of users were $\leq 19$ years old, and an additional $56 \%$ were 20 to 29 years old. ${ }^{30}$ On the other hand, research on Text4Baby in the United States showed that younger women with lower income and education were less likely to enroll in the subscription-based text message program for pregnant or parenting women than older, higher-income, and better-educated women. ${ }^{32}$

Studies of mHealth applications for screening and follow-up for STIs (Table 3) documented improved submission of biological samples for screening in Australia ${ }^{36}$ and the Netherlands ${ }^{37}$ and timely recall and treatment of youth who test positive for STIs in New Zealand, ${ }^{56}$ Australia, ${ }^{38}$ and the United States. ${ }^{39,54}$ An important finding from the Stamp Out Chlamydia program in Australia is that combining text messages with a small financial incentive to encourage screening resulted in a dramatically reduced time period for recruitment, from collecting 638 specimens in 6 months to collecting 472 specimens in just 4 days. ${ }^{36}$ Finally, 2 studies of HPV vaccination reminders sent via SMS to parents or teens in the United States yielded higher rates of receiving second and third doses of the HPV vaccine and more timely completion of the HPV vaccine series. ${ }^{34,35}$

Using the mobile phone to place calls to adolescent patients to conduct 


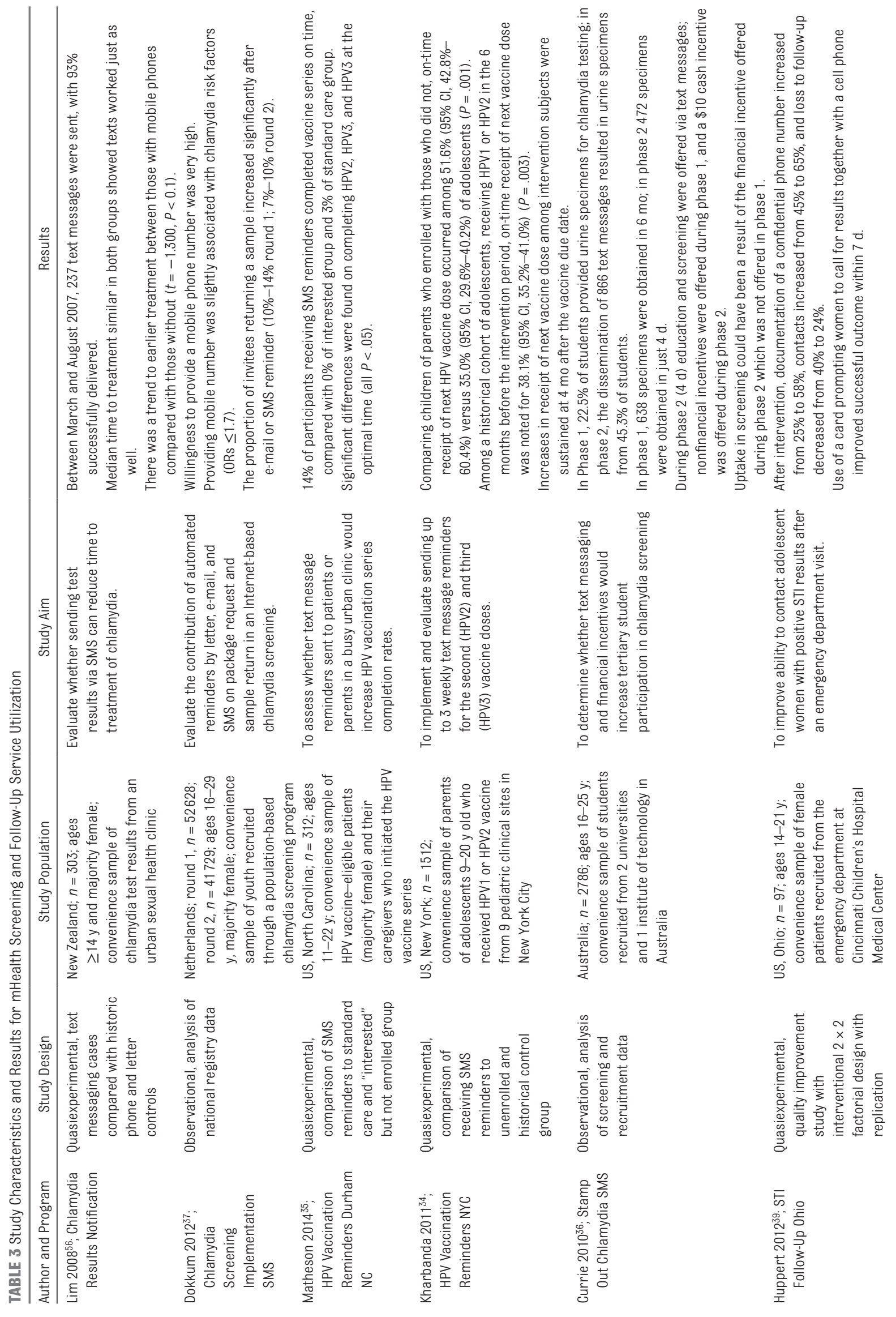




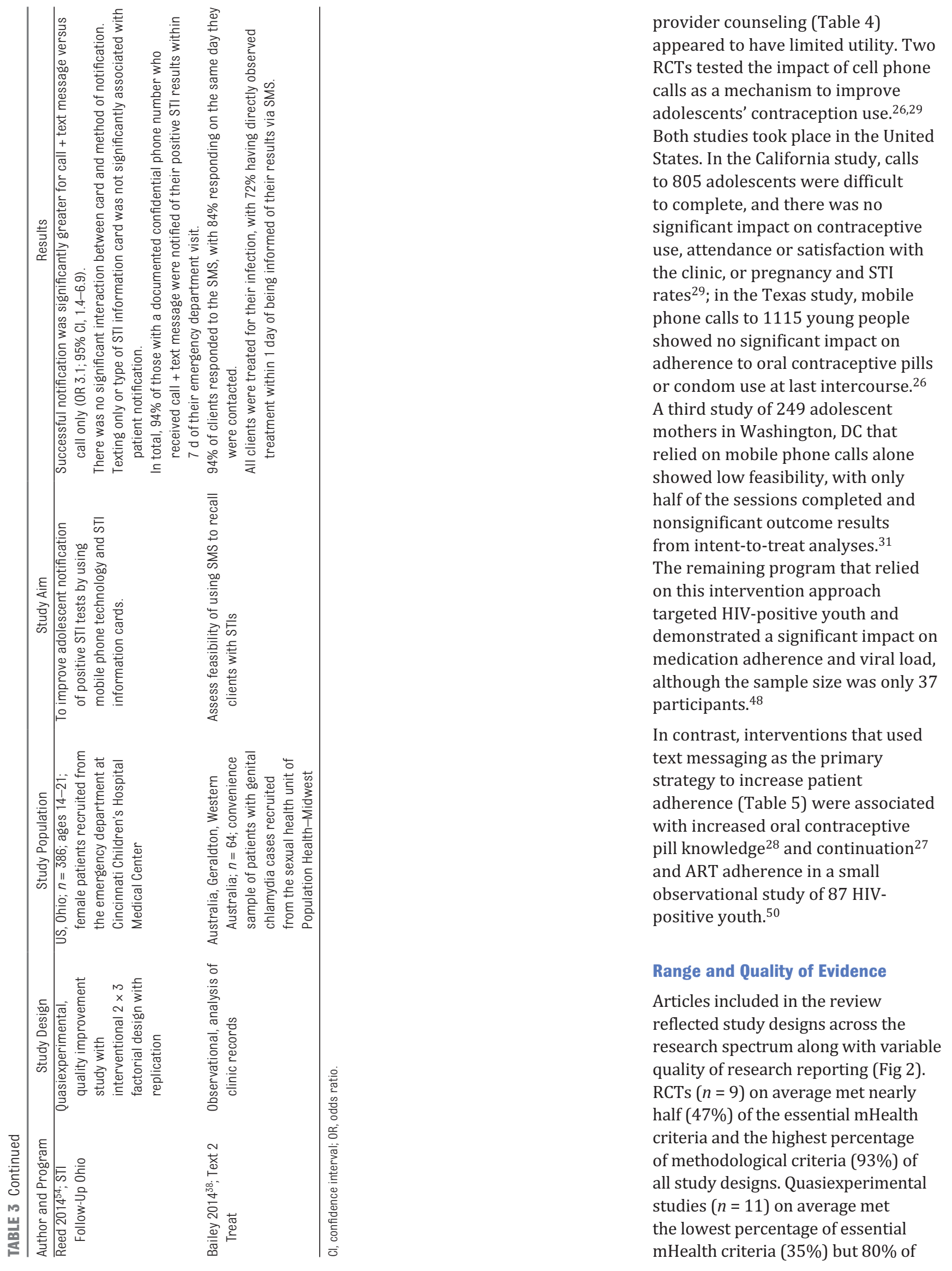


TABLE 4 Study Characteristics and Results for mHealth Provider Counseling

\begin{tabular}{|c|c|c|c|c|}
\hline $\begin{array}{l}\text { Author and } \\
\text { Program }\end{array}$ & Study Design & Study Population & Study Aim & Results \\
\hline $\begin{array}{l}\text { Belzer } 2014^{48} \\
\text { AdTriNet } \\
\text { YLHIV } \\
\text { Adherence } \\
\text { Facilitators }\end{array}$ & $\mathrm{RCT}$ & $\begin{array}{l}\text { US, nationwide; } n=37 \\
\text { ages } 15-24 \text { y; } 62 \% \\
\text { male and } 70 \% \text { African } \\
\text { American; convenience } \\
\text { sample of youth living } \\
\text { with HIV recruited from } \\
5 \text { Adolescent Trials } \\
\text { Network for HIV/AIDS } \\
\text { Interventions sites }\end{array}$ & $\begin{array}{l}\text { Whether youth living with } \\
\text { HIV receiving cell phone } \\
\text { support Monday through } \\
\text { Friday demonstrated } \\
\text { improved adherence and } \\
\text { viral control during the } 24- \\
\text { wk intervention and } 24 \text { wk } \\
\text { after intervention compared } \\
\text { with controls. }\end{array}$ & $\begin{array}{l}\text { Mean self-reported adherence was significantly higher in } \\
\text { the intervention group at } 24 \text { and } 48 \text { wk over the past } 3 \\
\text { mo }(P=.021), 1 \mathrm{mo}(P=.007) \text {, past week }(P=.036) \text {, and } \\
\text { past weekend }(P=.035) \text {. } \\
\text { Self-reports of } \geq 90 \% \text { adherence over the past } 3 \text { mo ( } P \\
=.046) \text {, last } 1 \mathrm{mo}(P=.020) \text {, last week }(P=.028) \text {, and } \\
\text { last weekend ( } P=.017) \text { were significantly higher in the } \\
\text { intervention group. } \\
\text { Mean log } 10 \text { viral load was significantly lower in the } \\
\text { intervention group than in the control group at } 24 \text { wk } \\
\text { (2.82 vs } 4.52 ; P=.002) \text { and at } 48 \text { wk ( } 3.23 \text { vs } 4.23 ; P= \\
.043) \text {. }\end{array}$ \\
\hline $\begin{array}{l}\text { Puccio } 2006^{51} \\
\text { AdTriNet } \\
\text { YLHIV } \\
\text { Adherence } \\
\text { Facilitators }\end{array}$ & $\begin{array}{l}\text { Observational, } \\
\text { regular phone } \\
\text { surveys and } \\
\text { laboratory data }\end{array}$ & $\begin{array}{l}\text { US, California; } n=8 \text {; ages } \\
\text { 16-24 y; convenience } \\
\text { sample of majority } \\
\text { male HIV-positive youth } \\
\text { recruited from a health } \\
\text { facility and known to } \\
\text { the research team }\end{array}$ & $\begin{array}{l}\text { Evaluate the practicality } \\
\text { and acceptability of } \\
\text { weekly mobile phone } \\
\text { call reminders to help } \\
\text { HIV-positive youth adhere } \\
\text { to ART. }\end{array}$ & $\begin{array}{l}\text { Participants found calls to be helpful, and level of } \\
\text { intrusion into daily lives was acceptable. } \\
\text { Little staff time is needed for making calls. } \\
\text { A 12-wk intervention was not adequate for most } \\
\text { participants. } \\
\text { Protocol should allow }>3 \text { missed calls for each } \\
\text { participant. }\end{array}$ \\
\hline $\begin{array}{l}\text { Kirby } 2010^{29} \\
\text { Project Reach } \\
\text { California }\end{array}$ & RCT & $\begin{array}{l}\text { US, California; } n=805 ; \\
\text { ages } 14-18 \text { y; young } \\
\text { women attending a } \\
\text { reproductive health } \\
\text { clinic in San Francisco }\end{array}$ & $\begin{array}{l}\text { Whether follow-up phone } \\
\text { calls from health care } \\
\text { practitioners to address } \\
\text { young women's concerns } \\
\text { can help sustain } \\
\text { contraceptive use. }\end{array}$ & $\begin{array}{l}\text { Clinic counselors completed only } 2.7 \text { calls per patient and } \\
\text { made } 7.8 \text { attempts for every completed call. } \\
\text { The project did not influence contraceptive behavior, clinic } \\
\text { attendance, satisfaction with the clinic, or rates of } \\
\text { pregnancy and STDs. }\end{array}$ \\
\hline $\begin{array}{l}\text { Berenson } \\
\text { 2012²6; Texas } \\
\text { OCP Reminder } \\
\text { Calls }\end{array}$ & RCT & $\begin{array}{l}\text { US, Texas; } n=1115 \\
\text { ages } 16-24 \text { y; female } \\
\text { patients attending a } \\
\text { reproductive health } \\
\text { clinic and requesting } \\
\text { OCPs in southeast } \\
\text { Texas }\end{array}$ & $\begin{array}{l}\text { To examine the effect of } \\
\text { clinic-based intervention } \\
\text { and a clinic-based plus } \\
\text { telephone intervention on } \\
\text { contraceptive adherence } \\
\text { among young women } \\
\text { initiating use of OCPs }\end{array}$ & $\begin{array}{l}\text { The intervention did not have a significant effect on OCP } \\
\text { continuation after } 3 \text { mo, } 6 \text { mo, or } 12 \text { mo. } \\
\text { Condom use at last sexual intercourse did not differ by } \\
\text { intervention. } \\
\text { No effect was observed on pregnancy and STI rates or } \\
\text { mean number of correctly used pill packs. }\end{array}$ \\
\hline $\begin{array}{l}\text { Katz 201131; NIH- } \\
\text { DC Girl Talk }\end{array}$ & RCT & $\begin{array}{l}\text { US, Washington, DC; ages } \\
\text { 15-19 y; primiparous } \\
\text { pregnant teens, } 88 \% \\
\text { African American, } \\
\text { recruited from prenatal } \\
\text { clinics and local high } \\
\text { schools }\end{array}$ & $\begin{array}{l}\text { To test the efficacy of weekly } \\
\text { cell phone counseling } \\
\text { sessions on preventing } \\
\text { repeat teen pregnancies. }\end{array}$ & $\begin{array}{l}\text { There was no difference in time to pregnancy in intent-to- } \\
\text { treat analyses. } \\
\text { Among teens } 15-17 \text { y old only, increasing treatment } \\
\text { intensity was significantly associated with longer time } \\
\text { to subsequent pregnancy (hazard ratio }=0.987 ; 95 \% \mathrm{Cl} \text {, } \\
0.977-0.997 ; P=.013 \text { ). } \\
\text { The mean number of sessions completed over the } 18-\mathrm{mo} \\
\text { counseling period was } 20 \pm 12 \text { sessions, or a mean } \\
\text { percentage of } 52 \% \text { of the possible sessions. }\end{array}$ \\
\hline
\end{tabular}

$\mathrm{Cl}$, confidence interval; $\mathrm{OCP}$, oral contraceptive pill.

methodological criteria. Observational studies $(n=10)$ on average met $40 \%$ of essential mHealth criteria and $73 \%$ of methodological criteria. Descriptive studies ( $n=5$ ) on average met nearly half of the mHealth criteria (47\%) but only $82 \%$ of methodological criteria.

Across all 35 studies, fewer criteria for essential mHealth reporting were met than criteria for methodological reporting. In the mERA checklist for mHealth reporting, an average of $41 \%$ (range $14 \%-79 \%$ ) of criteria was achieved among all 35 studies
(Fig 3). The mHealth criteria least commonly reported were contextual adaptation $(11 \%)$ and cost assessment (17\%). Only 3 mHealth reporting criteria were met in more than half of studies: intervention delivery (91\%), intervention content (60\%), and infrastructure (57\%). In the mERA reporting and methodology checklist, an average of $82 \%$ (range $52 \%-100 \%$ ) of criteria were met across all 35 studies (Fig 4). However, only about half of all graded articles met the criteria for assessing bias, calculating sample size, or having a comparator, and only one-third met criteria for presentation of the study logic model or consideration of generalizability of research findings.

Sample sizes and recruitment strategies were diverse, reflecting varied study designs and study aims. Sample sizes ranged from 8 respondents in a study to improve medication adherence among HIVpositive youth in California ${ }^{51}$ to 52628 youth who were contacted to undergo chlamydia screening 
TABLE 5 Study Characteristics and Results for mHealth Patient Adherence Programs

\begin{tabular}{|c|c|c|c|c|}
\hline $\begin{array}{l}\text { Author and } \\
\text { Program }\end{array}$ & Study Design & Study Population & Study Aim & Results \\
\hline $\begin{array}{l}\text { Castano } 2012^{27} \\
\text { PPFA 0CP } \\
\text { Reminder } \\
\text { Texts }\end{array}$ & $\mathrm{RCT}$ & $\begin{array}{l}\text { US, New York; } n=962 ; \\
\text { ages } \leq 25 \text { y; young } \\
\text { women recruited from } \\
\text { a Planned Parenthood } \\
\text { health center }\end{array}$ & $\begin{array}{l}\text { To estimate whether daily } \\
\text { educational text messages } \\
\text { affect OCP continuation at } \\
6 \text { mo. }\end{array}$ & $\begin{array}{l}\text { At follow-up, } 64 \% \text { of intervention group were still } 0 \mathrm{CP} \\
\text { users, compared with } 54 \% \text { of control group }(P=.005) \text {. } \\
\text { Participants receiving intervention were more likely to } \\
\text { continue 0CP use at } 6 \text { mo (OR }=1.55 ; 95 \% \mathrm{Cl}, 1.03-2.00) \text {, } \\
\text { in analysis adjusted for age, race, ethnicity, age at first } \\
\text { sex, pregnancy history, and OCP experience. } \\
\text { Six-month OCP use improved by } 10 \% \text { in intervention versus } \\
\text { control group. }\end{array}$ \\
\hline $\begin{array}{l}\text { Hall } 2013^{28} \\
\text { PPFA 0CP } \\
\text { Reminder } \\
\text { Texts }\end{array}$ & $\mathrm{RCT}$ & $\begin{array}{l}\text { US, New York; } n=659 ; \\
\text { ages } 13-25 \text { y; young } \\
\text { women recruited from } \\
\text { a Planned Parenthood } \\
\text { health center }\end{array}$ & $\begin{array}{l}\text { To estimate whether daily } \\
\text { educational text messages } \\
\text { affect OCP knowledge at } \\
6 \text { mo. }\end{array}$ & $\begin{array}{l}\text { Mean 0CP knowledge scores improved over time for all } \\
\text { women (baseline } 22.8,56 \% \text { correct vs } 24.7,60 \% \text { at } 6 \\
\text { mo), including knowledge of } 0 \mathrm{CP} \text { mechanisms of action } \\
\quad(P=.004) \text {, effectiveness }(P<.001) \text {, side effects }(P=.03) \text {, } \\
\text { and benefits }(P<.001) \text {. } \\
\text { Mean 6-mo scores were greater in the intervention (25.5) } \\
\text { than the control group ( } 23.7)(P<.001) \text {. } \\
\text { Text message intervention most strongly predicted 0CP } \\
\text { knowledge }(\beta=1.6 ; 95 \% \mathrm{Cl}, 0.9-2.2) \text {. }\end{array}$ \\
\hline $\begin{array}{l}\text { Hailey } 2013^{50} \text {; } \\
\text { STAR TRACK } \\
\text { ST-AMP }\end{array}$ & $\begin{array}{l}\text { Observational, } \\
\text { analysis of } \\
\text { self-reported } \\
\text { adherence data }\end{array}$ & $\begin{array}{l}\text { US, Maryland; } n=87 \text {; ages } \\
\text { 15-24 y; convenience } \\
\text { sample of mostly } \\
\text { African American and } \\
\text { male primary care } \\
\text { patients recruited from } \\
\text { a the STAR TRACK clinic }\end{array}$ & $\begin{array}{l}\text { To evaluate whether STAR } \\
\text { TRACK Adherence to } \\
\text { Medication text and video } \\
\text { messaging program } \\
\text { improves adherence to ART } \\
\text { and HIV care. }\end{array}$ & $\begin{array}{l}\text { Before ST-AMP was implemented, patient self-reports } \\
\text { indicated that their adherence to ART was roughly } \\
40 \%-50 \% \text {; in patients enrolled in ST-AMP, overall ART } \\
\text { adherence increased to } \sim 80 \% \text { within } 24 \text { mo. }\end{array}$ \\
\hline $\begin{array}{l}\text { Dowshen } \\
\text { 201349; YLH } \\
\text { Philadelphia }\end{array}$ & $\begin{array}{l}\text { Observational, } \\
\text { analysis of } \\
\text { electronic data } \\
\text { log and SMS } \\
\text { responses, } \\
\text { periodic } \\
\text { interviews } \\
\text { assessing } \\
\text { self-reported } \\
\text { adherence }\end{array}$ & $\begin{array}{l}\text { US, Pennsylvania; } n= \\
25 \text {; ages } 14-29 \text { y; } \\
\text { convenience sample } \\
\text { of HIV-positive youth, } \\
60 \% \text { African American } \\
\text { and majority male, } \\
\text { recruited from a } \\
\text { community center for } \\
\text { lesbian, gay, bisexual, } \\
\text { and transgender youth }\end{array}$ & $\begin{array}{l}\text { To assess the feasibility and } \\
\text { validity of daily ITR as a } \\
\text { measure of adherence to } \\
\text { ART among youth living } \\
\text { with HIV. }\end{array}$ & $\begin{array}{l}\text { Participants responded to medication prompts } \sim 61 \% \text { of } \\
\text { the time. } \\
\text { The overall mean ITR adherence rate (ie, positive } \\
\text { responses) was } 57.4 \% \text { (SD }=28.5 \% \text { ); ITR and visual } \\
\text { analog scale measures were moderately positively } \\
\text { correlated ( } r=0.52, P<.05 \text { ) during the first } 6 \text { wk of the } \\
\text { study period. } \\
\text { ITR adherence rates were significantly higher on weekdays } \\
\text { than on weekends ( } P<.05 \text { ). } \\
\text { ITR method provides a helpful tool to identify and respond } \\
\text { to adherence challenges in real time. }\end{array}$ \\
\hline
\end{tabular}

$\mathrm{Cl}$, confidence interval; ITR, interactive text message response; $\mathrm{OCP}$, oral contraceptive pill; $0 \mathrm{R}$, odds ratio.

in an observational study in the Netherlands. ${ }^{37}$ Most studies recruited youth participants from health care facilities and clinics, several used community organizations and schools, and population-based studies relied on national registries, mass media advertising, and community events such as music festivals.

\section{DISCUSSION}

\section{mHealth Program Strategies}

The diversity and ingenuity of mHealth intervention programs identified in this review reflect how ASRH professionals are embracing mobile phones to improve adolescents' health at myriad levels of the health care system. The interventions identified for this review aimed to promote positive and preventive SRH behaviors, increase adoption and continuation of contraception, support medication adherence for HIV-positive young people, support teen parents, and encourage use of health screening and treatment services. Mobile phones were used to increase health program reach to adolescents and ethnic and minority subgroups, increase confidentiality in providing sensitive SRH information to young people, and provide a supportive "friend in your pocket" who reminds and encourages good health.

The large majority of mHealth interventions for ASRH relied on
SMS platforms. Notably, only 4 mHealth programs included in this review used other technological communication formats in place of or in addition to SMS. From a programmatic lens this is a strategic and defensible choice because SMS remains the most frequently used mobile phone communication format among youth in the world and is often cost-effective, costing just pennies per text at implementation. . $^{2,5,57}$ However, text messaging requires clear and concise content within the 160-character restrictions of SMS and basic literacy for reading and understanding message content. Overall, mHealth interventions demand substantial attention to the user interface and content 


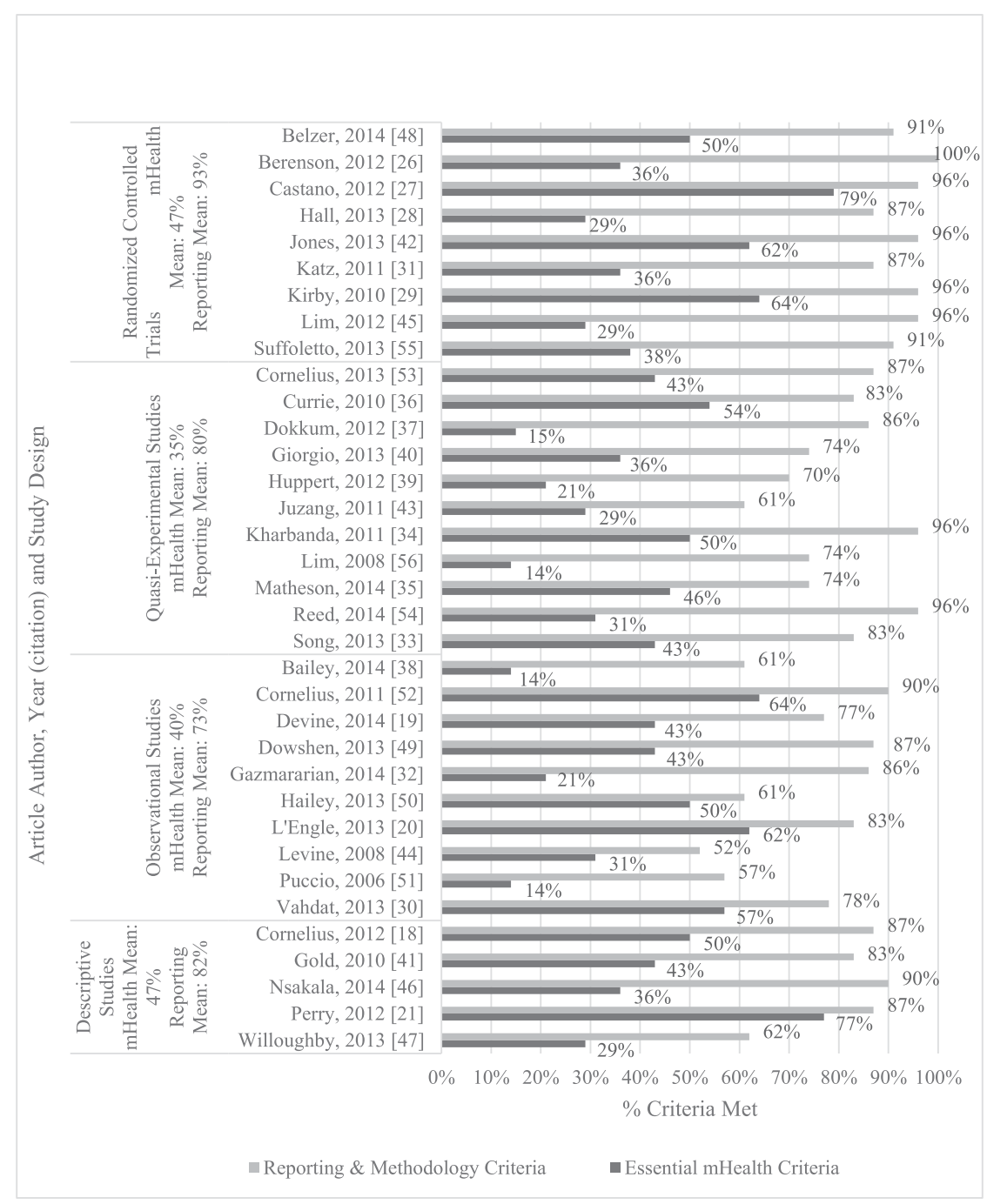

FIGURE 2

Percentage of mERA reporting criteria met, by article and study design.

delivery, yet there is limited knowledge of best practices in mobile phone communication for health promotion. ${ }^{58}$ Because smartphone and Internet adoption is increasing globally, ASRH professionals should give greater consideration to message content, developing and testing additional communication formats, and criteria for evaluating these innovations.

\section{Summary of Evidence}

Although the mHealth field has been criticized for producing limited evidence about efficacy and effectiveness of mHealth interventions, ${ }^{59-61}$ a variety of robust research designs and methods were used in the 35 studies we identified. The 9 RCTs tested the impact of the mHealth intervention on SRH knowledge, sexual behavior, medication adherence, and contraception use, among other ASRH outcomes. Many of the 11 quasiexperimental studies focused on quality improvement of health service delivery and relied on uptake of health screening and treatment services to assess effectiveness of the mHealth intervention. The 10 observational research studies tended to focus on implementation of the mHealth program to track reach and adoption by using a variety of methods such as electronic data monitoring, analysis of national registry data, in-person interviews, and phone calls to participants. The 5 descriptive studies used qualitative methods such as focus group discussions but also content analyses of SRH questions posed by adolescents to assess reactions to intervention content or delivery. This variety of research designs, methods, and aims indicates the development of a robust evidence base at the intersection of mobile phones and ASRH.

Findings from the reviewed studies provide support for distinct uses of mobile phones to improve ASRH. First, health promotion campaigns implemented with text messaging evidenced robust acceptability and relevance for young people globally and led to improved SRH knowledge, less unprotected sex, and more STI testing. Additionally, young people across races and genders accessed these health promotion programs, suggesting excellent reach into the general youth population and key youth subgroups. Data from both higher-income countries and lowerincome countries (LICs) suggests widespread youth access, although caution is needed in reaching conclusions about young people in LICs because few of the included studies were conducted in these settings. Second, leveraging mobile phones to increase youth contact for STI screening and follow-up yielded higher rates of screening and recall and more timely and complete STI treatment and vaccination. These results were found across this body of research conducted in Australia, the Netherlands, New Zealand, and the United States. Third, using text messaging to increase adolescent patient adherence to medication (oral contraceptive pills and ART) was shown to be promising in experimental research conducted with adolescents in the United States. However, using mobile phone 


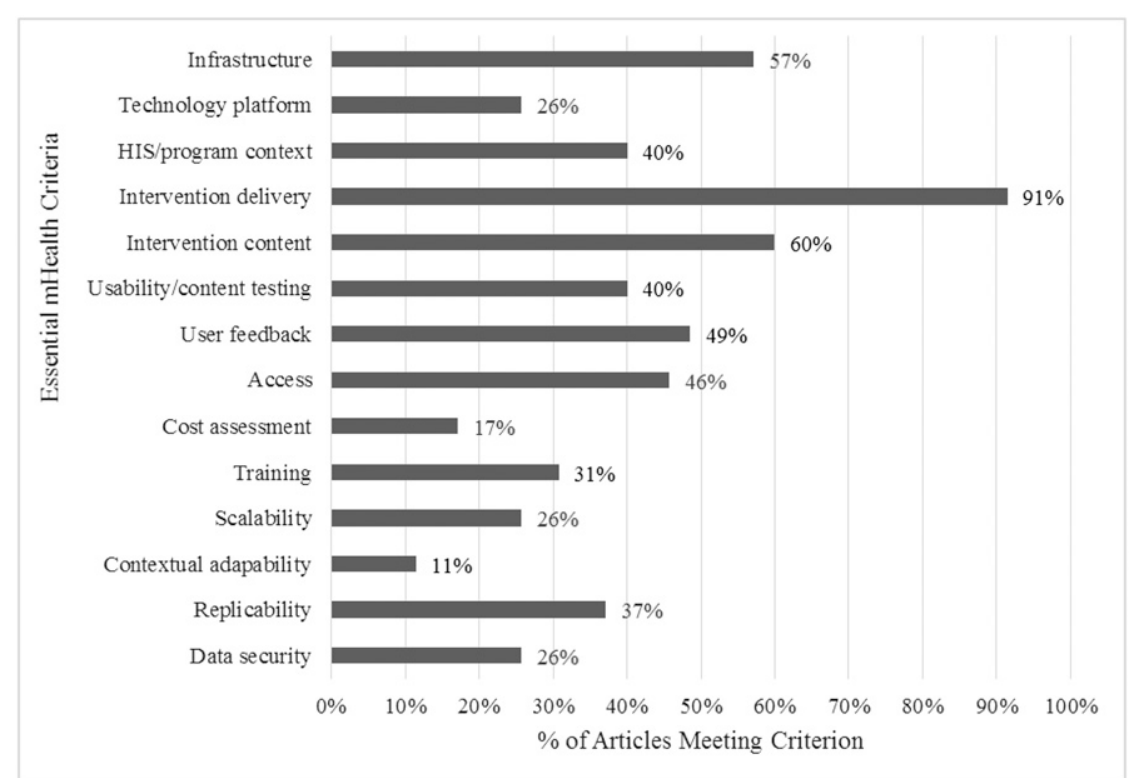

FIGURE 3

Percentage of articles that met mERA essential mHealth criteria. HIS, health information system.

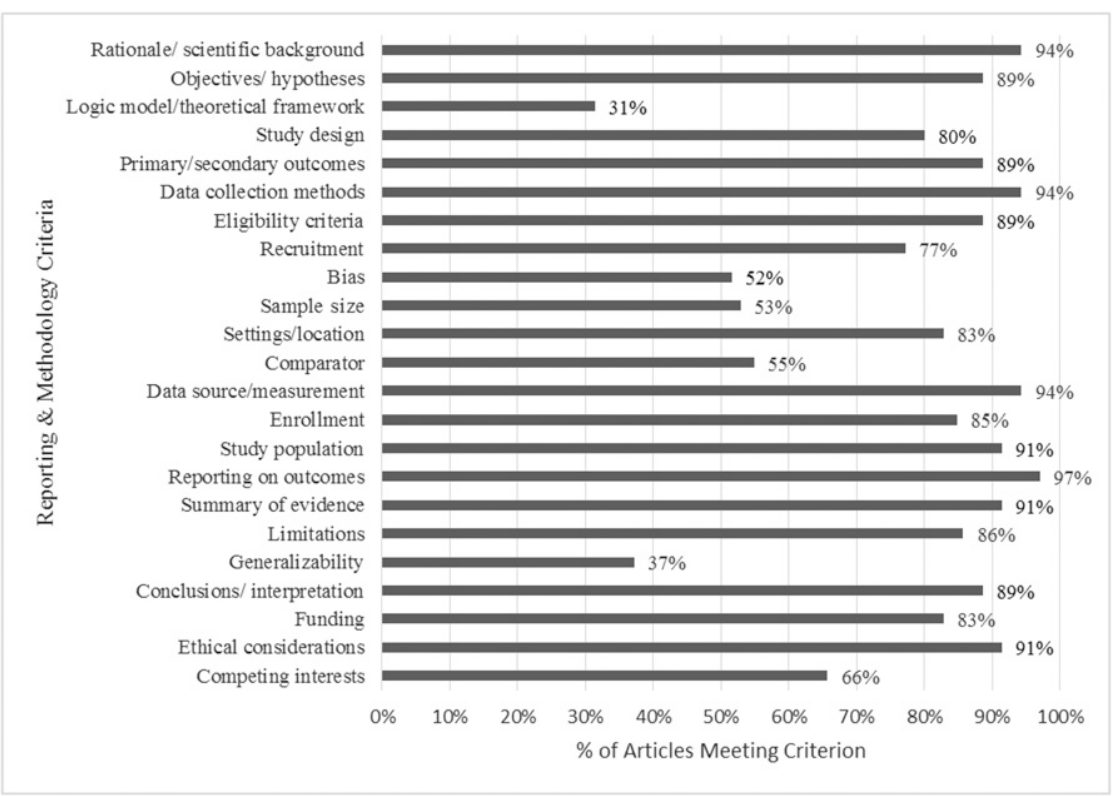

FIGURE 4

Percentage of articles that met mERA reporting and methodology criteria.

calls to provide adolescent patient counseling was ineffective, except for 1 small study of HIV-positive young people. Therefore, results from this review suggest that programs that aim to improve adolescents' adherence to medication should use text messaging rather than phone calls for reminders and support and that more research should be conducted in this important area.

\section{mERA Checklist}

The mERA checklist provided a valuable platform for assessing the range and quality of reporting on mHealth interventions for ASRH. Notably, twice the percentage of mERA reporting and methodology criteria were met (81\%) compared with essential mHealth criteria (41\%), reflecting a high degree of reporting and methodology quality in the 35 reviewed studies and a lower level of reporting completeness on essential features of the mHealth intervention. Guidelines for research reporting are widely available, and our results suggest high dissemination of reporting standards regardless of study design. On the other hand, reporting on mHealth programs is new, and the mERA checklist is the first reporting tool available for complete and transparent reporting on mHealth intervention research. Therefore, low scores for essential mHealth reporting are unsurprising. Increased dissemination and adoption of the mERA checklist will facilitate better reporting and improved ability to synthesize evidence on mHealth interventions.

Only 3 articles in this review studied mHealth interventions for young people in LICs. ${ }^{20,30,46}$ The dearth of peer-reviewed evidence from LIC contexts is concerning, especially in light of the high use of mobile phones in these settings and existing reports that have identified many mobile phone interventions in LICs. ${ }^{62,63}$ Robust research is needed to make evidence-based recommendations about the strategic use of mobile phones to improve ASRH in LICs, where limited resources make the need for evidence about impactful and cost-effective programs even more pressing. It is possible that our search strategy failed to identify peer-reviewed studies from LICs, although the global call for resources was disseminated through numerous channels to tap health researchers and programs in both high-income countries and LICs. In addition, we may have inadvertently excluded eligible articles during screening, and relevant studies 
may have been discounted because they were not published in peerreviewed journals or in English, in accordance with our study eligibility requirements. Finally, the mERA checklist is in its infancy, and this review is the first to apply the criteria in their entirety and with some of the rigor of the PRISMA guidelines, and therefore mERA grading results should be considered with caution.

\section{CONCLUSIONS}

This review highlights many innovative, youth-engaging, and effective uses of mobile phones to improve ASRH globally, but room remains for additional evidence and innovation. Research on mHealth interventions increasingly uses robust research designs and is accumulating evidence about the potential impact on ASRH knowledge, behavior, and service utilization. Yet the evidence base would benefit from larger sample sizes, more experimental studies, and primary outcomes focused on a variety of SRH norms and behaviors. Conducting this research in LICs is imperative.

Additional research also is needed to determine the optimal communication format for mobile phone interventions for ASRH. Data on the cost and cost-effectiveness of mHealth interventions for improving ASRH outcomes, along with costeffectiveness data comparing mobile phones with other communication channels (such as in-person counseling or community outreach events) also would be beneficial. Finally, as the field matures, we hope the mERA checklist will serve as an important tool to support mHealth evidence evaluation, synthesis, and generation of best practices for adolescents' health.

\section{ACKNOWLEDGMENTS}

We thank Kate Plourde for support with gathering resources and abstracting studies, and Garret Mehl, Tigest Tamrat, and Lianne Gonsalves for support on search terms and the global call for resources. Details of how to obtain additional data from the study (codebook and dataset) are available from the corresponding author.

ABBREVIATIONS
ART: antiretroviral therapy
ASRH: adolescent sexual and
reproductive health
HPV: human papillomavirus
LIC: lower-income country
m4RH: Mobile for Reproductive
$\quad$ Health
mERA: mHealth Evidence and
$\quad$ Reporting Assessment
mHealth: mobile phone
$\quad$ interventions for health
$\quad$ improvement
PRISMA: Preferred Reporting
$\quad$ Items for Systematic
$\quad$ Review and
$\quad$ Meta-Analyses
RCT: randomized controlled trial
SRH: sexual and reproductive
health
SMS: Short Message Service
infection

reviewed and revised the manuscript; Ms Ippoliti performed data coding and extraction, contributed to the interpretation of data, and critically reviewed the manuscript; and all authors approved the final manuscript as submitted.

DOI: $10.1542 /$ peds.2016-0884

Accepted for publication Jun 29, 2016

Address correspondence to Kelly L. L'Engle, PhD, MPH, School of Nursing and Health Professions, University of San Francisco, 2130 Fulton St, San Francisco, CA 94117. E-mail: klengle@usfca.edu

PEDIATRICS (ISSN Numbers: Print, 0031-4005; Online, 1098-4275).

Copyright @ 2016 by the American Academy of Pediatrics

FINANCIAL DIScLOSURE: The authors have indicated they have no financial relationships relevant to this article to disclose.

FUNDING: The World Health Organization, Department of Reproductive Health and Research, funded the review. Additional support was provided by the US Agency for International Development (USAID) through the Knowledge for Health project. The funders had no influence on the process or conclusions of the article. The views expressed are those of the authors and not necessarily those of the World Health Organization or USAID. Dr Agarwal and Ms Mangone were supported by the FHI360-UNC Research Fellowship.

POTENTIAL CONFLICT OF INTEREST: The authors have indicated they have no potential conflicts of interest to disclose.

\section{REFERENCES}

1. International Telecommunication Union (ITU). ICT Facts \& Figures: The World in 2015. Geneva, Switzerland: ITU; 2015. Available at: www.itu.int/ en/ITU-D/Statistics/Documents/facts/ ICTFactsFigures2015.pdf
2. Pew Research Center. Emerging Nations Embrace Internet, Mobile Technology. Washington, DC: Pew Research Center; 2014. Available at: www.pewglobal.org/files/2014/02/ Pew-Research-Center-Global-Attitudes-
Project-Technology-Report-FINALFebruary-13-20147.pdf

3. GSMA. The Mobile Economy 2015. Available at: www.gsmamobileeconomy com/GSMA_Global_Mobile_Economy_ Report_2015.pdf 
4. International Telecommunication Union (ITU). The World in 2011: ICT Facts and Figures. Geneva, Switzerland: ITU; 2011. Available at: www.itu.int/ITU-D/ict/ facts/2011/material/ICTFactsFigures20 11.pdf

5. Nielsen Company. Mobile Youth Around the World 2010. Available at: www. nielsen.com/us/en/insights/reports/ 2010/mobile-youth-around-the-world. html.

6. Lenhart A. Teens, Social Media, \& Technology Overview 2015. Washington, DC: Pew Research Center; 2015, Available at: www.pewinternet.org/ files/2015/04/PI_TeensandTech_ Update2015_0409151.pdf

7. Gonsalves L, L'Engle KL, Tamrat T, et al. Adolescent/Youth Reproductive Mobile Access and Delivery Initiative for Love and Life Outcomes (ARMADILLO) Study: formative protocol for mHealth platform development and piloting. Reprod Health. 2015;12(67):67

8. Hightow-Weidman LB, Muessig KE, Bauermeister J, Zhang C, LeGrand S. Youth, technology, and HIV: recent advances and future directions. Curr HIV/AIDS Rep. 2015;12(4):500-515

9. Jones K, Eathington P, Baldwin K, Sipsma $H$. The impact of health education transmitted via social media or text messaging on adolescent and young adult risky sexual behavior: a systematic review of the literature. Sex Transm Dis. 2014;41(7):413-419

10. Lim MSC, Hocking JS, Hellard ME, Aitken CK. SMS STI: a review of the uses of mobile phone text messaging in sexual health. Int J STD AIDS. 2008;19(5):287-290

11. Mulye TP, Park MJ, Nelson CD, Adams $\mathrm{SH}$, Irwin CE Jr, Brindis CD. Trends in adolescent and young adult health in the United States. J Adolesc Health. 2009;45(1):8-24

12. Xu JS, Shtarkshall R. Determinants, outcomes and interventions of teenage pregnancy: an international perspective. Reprod Contracept. 2004;15(1):9-18

13. Biddlecom AE, Munthali A, Singh $S$, Woog V. Adolescents' views of and preferences for sexual and reproductive health services in Burkina Faso, Ghana, Malawi and Uganda. Afr J Reprod Health. 2007;11(3):99-110

14. Chandra-Mouli V, McCarraher DR, Phillips SJ, Williamson NE, Hainsworth G. Contraception for adolescents in low and middle income countries: needs, barriers, and access. Reprod Health. 2014;11(1):1

15. Delany-Moretlwe S, Cowan FM, Busza J, Bolton-Moore C, Kelley K, Fairlie L. Providing comprehensive health services for young key populations: needs, barriers and gaps. J Int AIDS Soc. 2015;18(2 suppl 1):19833

16. Kerr JC, Valois RF, Diclemente RJ, et al. HIV-related stigma among African-American youth in the Northeast and Southeast US. AIDS Behav. 2014;18(6):1063-1067

17. Tilson EC, Sanchez V, Ford CL, et al. Barriers to asymptomatic screening and other STD services for adolescents and young adults: focus group discussions. BMC Public Health. 2004;4(21):1-8

18. Cornelius JB, St Lawrence JS, Howard $\mathrm{JC}$, et al. Adolescents' perceptions of a mobile cell phone text messagingenhanced intervention and development of a mobile cell phone-based HIV prevention intervention. J Spec Pediatr Nurs. 2012;17(1):61-69

19. Devine S, Bull S, Dreisbach S, Shlay J. Enhancing a teen pregnancy prevention program with text messaging: engaging minority youth to develop TOP ${ }^{\circledR}$ Plus Text. J Adolesc Health. 2014;54(3 suppl):S78-S83

20. L'Engle KL, Vahdat HL, Ndakidemi E, Lasway C, Zan T. Evaluating feasibility, reach and potential impact of a text message family planning information service in Tanzania. Contraception. 2013;87 (2):251-256

21. Perry RCW, Kayekjian KC, Braun RA, Cantu M, Sheoran B, Chung PJ. Adolescents' perspectives on the use of a text messaging service for preventive sexual health promotion. J Adolesc Health. 2012;51(3):220-225

22. Agarwal SA, LeFevre AE, Lee J, et al. Guidelines for reporting mHealth evidence: the mHealth Evidence Reporting and Assessment (mERA) tool. BMJ. 2016;352:i1174

23. World Health Organization (WHO). The Health of Youth Document A42/
Technical Discussions/2. Geneva, Switzerland: WHO; 1989

24. United National Family Planning Association (UNFPA). Making Reproductive Rights and Sexual Health a Reality for All. New York, NY: UNFPA; 2008

25. Moher D, Liberati A, Tetzlaff J, Altman DG; PRISMA Group. Preferred reporting items for systematic reviews and meta-analyses: the PRISMA statement. PLoS Med. 2009;6(7):e1000097

26. Berenson AB, Rahman M. A randomized controlled study of two educational interventions on adherence with oral contraceptives and condoms. Contraception. 2012;86(6):716-724

27. Castaño PM, Bynum JY, Andrés R, Lara M, Westhoff C. Effect of daily text messages on oral contraceptive continuation: a randomized controlled trial. Obstet Gynecol. 2012;119(1):14-20

28. Hall KS, Westhoff CL, Castaño PM. The impact of an educational text message intervention on young urban women's knowledge of oral contraception. Contraception. 2013;87(4):449-454

29. Kirby D, Raine T, Thrush G, Yuen C, Sokoloff A, Potter SC. Impact of an intervention to improve contraceptive use through follow-up phone calls to female adolescent clinic patients. Perspect Sex Reprod Health. 2010;42(4):251-257

30. Vahdat HL, L'Engle KL, Plourde KF, Magaria L, Olawo A. There are some questions you may not ask in a clinic: providing contraception information to young people in Kenya using SMS. Int J Gynaecol Obstet. 2013;123(suppl 1):e2-e6

31. Katz KS, Rodan M, Milligan R, et al. Efficacy of a randomized cell phonebased counseling intervention in postponing subsequent pregnancy among teen mothers. Matern Child Health J. 2011;15(suppl 1):S42-S53

32. Gazmararian JA, Elon L, Yang B, Graham M, Parker R. Text4baby program: an opportunity to reach underserved pregnant and postpartum women? Matern Child Health J. 2014;18(1):223-232

33. Song H, May A, Vaidhyanathan V, Cramer EM, Owais RW, McRoy S. A twoway text-messaging system answering health questions for low-income 
pregnant women. Patient Educ Couns. 2013;92(2):182-187

34. Kharbanda EO, Stockwell MS, Fox HW, Andres R, Lara M, Rickert VI. Text message reminders to promote human papillomavirus vaccination. Vaccine. 2011;29(14):2537-2541

35. Matheson EC, Derouin A, Gagliano M, Thompson JA, Blood-Siegfried J. Increasing HPV vaccination series completion rates via text message reminders. J Pediatr Health Care. 2014;28(4):e35-e39

36. Currie MJ, Schmidt M, Davis BK, et al. "Show me the money": financial incentives increase chlamydia screening rates among tertiary students: a pilot study. Sex Health. 2010;7 (1):60-65

37. Dokkum NFB, Koekenbier RH, van den Broek IVF, et al. Keeping participants on board: increasing uptake by automated respondent reminders in an Internet-based chlamydia screening in the Netherlands. BMC Public Health. 2012;12:176

38. Bailey SM, Scalley BC, Gilles MT. Text 2 treat: using SMS to recall clients for treatment. Int J STD AIDS. 2014;25(14):1-3

39. Huppert JS, Reed JL, Munafo JK, et al. Improving notification of sexually transmitted infections: a quality improvement project and planned experiment. Pediatrics. 2012;130(2). Available at: www.pediatrics.org/cgi/ content/full/130/2/e415

40. Giorgio MM, Kantor LM, Levine DS, Arons W. Using chat and text technologies to answer sexual and reproductive health questions: Planned Parenthood pilot study. J Med Internet Res. 2013;15(9):e203

41. Gold J, Lim MSC, Hellard ME, Hocking JS, Keogh L. What's in a message? Delivering sexual health promotion to young people in Australia via text messaging. BMC Public Health. 2010;10:792

42. Jones R, Hoover DR, Lacroix LJ. A randomized controlled trial of soap opera videos streamed to smartphones to reduce risk of sexually transmitted human immunodeficiency virus (HIV) in young urban African American women. Nurs Outlook. 2013;61(4):205-215.e3

43. Juzang I, Fortune T, Black S, Wright E, Bull S. A pilot programme using mobile phones for HIV prevention. J Telemed Telecare. 2011;17(3):150-153

44. Levine D, McCright J, Dobkin L, Woodruff AJ, Klausner JD. SEXINFO: a sexual health text messaging service for San Francisco youth. Am J Public Health. 2008;98(3):393-395

45. Lim MSC, Hocking JS, Aitken CK, et al. Impact of text and email messaging on the sexual health of young people: a randomised controlled trial. J Epidemiol Community Health. 2012;66(1):69-74

46. Nsakala GV, Coppieters Y, Kayembe PK. An innovative approach to using both cellphones and the radio to identify young people's sexual concerns in Kinshasa, Democratic Republic of Congo. Arch Public Health. 2014;72(1):21

47. Willoughby JF, Jackson K. "Can you get pregnant when u $r$ in the pool?": young people's information seeking from a sexual health text line. Sex Educ. 2013;13(1):96-101

48. Belzer ME, Naar-King S, Olson J, et al; Adolescent Medicine Trials Network for HIV/AIDS Interventions. The use of cell phone support for non-adherent HIV-infected youth and young adults: an initial randomized and controlled intervention trial. AIDS Behav. 2014;18(4):686-696

49. Dowshen N, Kuhns LM, Gray C, Lee S, Garofalo R. Feasibility of interactive text message response (ITR) as a novel, real-time measure of adherence to antiretroviral therapy for HIV+ youth. AIDS Behav. 2013;17 (6):2237-2243

50. Hailey JH, Arscott J. Using technology to effectively engage adolescents and young adults into care: STAR TRACK Adherence Program. J Assoc Nurses AIDS Care. 2013;24(6):582-586

51. Puccio JA, Belzer M, Olson J, et al. The use of cell phone reminder calls for assisting HIV-infected adolescents and young adults to adhere to highly active antiretroviral therapy: a pilot study. AIDS Patient Care STDS. 2006;20(6):438-444

52. Cornelius JB, Cato M, Lawrence JS, Boyer CB, Lightfoot M. Development and pretesting multimedia HIVprevention text messages for mobile cell phone delivery. J Assoc Nurses AIDS Care. 2011;22(5):407-413
53. Cornelius JB, Dmochowski J, Boyer C, St Lawrence J, Lightfoot M, Moore M. Text-messaging-enhanced HIV intervention for African American adolescents: a feasibility study. J Assoc Nurses AIDS Care. 2013;24(3):256-267

54. Reed JL, Huppert JS, Taylor RG, et al. Improving sexually transmitted infection results notification via mobile phone technology. J Adolesc Health. 2014;55(5):690-697

55. Suffoletto B, Akers A, McGinnis KA, Calabria J, Wiesenfeld HC, Clark DB. A sex risk reduction text-message program for young adult females discharged from the emergency department. J Adolesc Health. 2013;53(3):387-393

56. Lim EJ, Haar J, Morgan J. Can text messaging results reduce time to treatment of Chlamydia trachomatis? Sex Transm Infect. 2008;84(7):563-564

57. Mangone ER, Agarwal S, L'Engle K, et al. Sustainable cost models for mHealth at scale: modeling program data from m4RH Tanzania. PLoS One. 2016;11(1):e0148011

58. Head KJ, Noar SM, lannarino NT, Grant Harrington N. Efficacy of text messaging-based interventions for health promotion: a meta-analysis. Soc Sci Med. 2013;97:41-48

59. Al-Shorbaji N, Geissbuhler A. Establishing an evidence base for e-health: the proof is in the pudding. Bull World Health Organ. 2012;90(5):322-322A

60. Kumar S, Nilsen WJ, Abernethy A, et al. Mobile health technology evaluation: the mHealth evidence workshop. Am J Prev Med. 2013;45(2):228-236

61. Tomlinson M, Rotheram-Borus MJ, Swartz L, Tsai AC. Scaling up mHealth: where is the evidence? PLoS Med. 2013;10(2): e1001382

62. Lee SH, Nurmatov UB, Nwaru BI, Mukherjee M, Grant L, Pagliari C. Effectiveness of mHealth interventions for maternal, newborn and child health in low- and middle-income countries: systematic review and meta-analysis. J Glob Health. 2016;6(1):010401

63. Levine R, Corbacio A, Konopka S, et al. African Strategies for Health. mHealth Compendium. Arlington, VA: Management Sciences for Health; 2015 
Mobile Phone Interventions for Adolescent Sexual and Reproductive Health: A Systematic Review

Kelly L. L'Engle, Emily R. Mangone, Angela M. Parcesepe, Smisha Agarwal and Nicole B. Ippoliti

Pediatrics 2016;138;

DOI: 10.1542/peds.2016-0884 originally published online August 23, 2016;

\begin{tabular}{|c|c|}
\hline $\begin{array}{l}\text { Updated Information \& } \\
\text { Services }\end{array}$ & $\begin{array}{l}\text { including high resolution figures, can be found at: } \\
\text { http://pediatrics.aappublications.org/content/138/3/e20160884 }\end{array}$ \\
\hline References & $\begin{array}{l}\text { This article cites } 54 \text { articles, } 4 \text { of which you can access for free at: } \\
\text { http://pediatrics.aappublications.org/content/138/3/e20160884\#BIBL }\end{array}$ \\
\hline Subspecialty Collections & $\begin{array}{l}\text { This article, along with others on similar topics, appears in the } \\
\text { following collection(s): } \\
\text { Health Information Technology } \\
\text { http://www.aappublications.org/cgi/collection/health_information_te } \\
\text { chnology_sub } \\
\text { Adolescent Health/Medicine } \\
\text { http://www.aappublications.org/cgi/collection/adolescent_health:med } \\
\text { icine_sub }\end{array}$ \\
\hline Permissions \& Licensing & $\begin{array}{l}\text { Information about reproducing this article in parts (figures, tables) or } \\
\text { in its entirety can be found online at: } \\
\text { http://www.aappublications.org/site/misc/Permissions.xhtml }\end{array}$ \\
\hline Reprints & $\begin{array}{l}\text { Information about ordering reprints can be found online: } \\
\text { http://www.aappublications.org/site/misc/reprints.xhtml }\end{array}$ \\
\hline
\end{tabular}




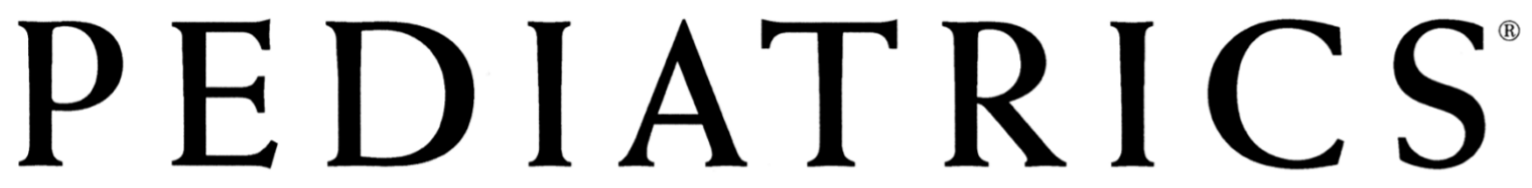

OFFICIAL JOURNAL OF THE AMERICAN ACADEMY OF PEDIATRICS

Mobile Phone Interventions for Adolescent Sexual and Reproductive Health: A Systematic Review

Kelly L. L'Engle, Emily R. Mangone, Angela M. Parcesepe, Smisha Agarwal and Nicole B. Ippoliti

Pediatrics 2016;138;

DOI: 10.1542/peds.2016-0884 originally published online August 23, 2016;

The online version of this article, along with updated information and services, is located on the World Wide Web at:

http://pediatrics.aappublications.org/content/138/3/e20160884

Data Supplement at:

http://pediatrics.aappublications.org/content/suppl/2016/08/22/peds.2016-0884.DCSupplemental

Pediatrics is the official journal of the American Academy of Pediatrics. A monthly publication, it has been published continuously since 1948. Pediatrics is owned, published, and trademarked by the American Academy of Pediatrics, 141 Northwest Point Boulevard, Elk Grove Village, Illinois, 60007. Copyright $\odot 2016$ by the American Academy of Pediatrics. All rights reserved. Print ISSN: 1073-0397. 